TITLE:

\title{
Effects of oral intake of hydrogen water on liver fibrogenesis in mice( Abstract_要旨 )
}

AUTHOR(S):

Koyama, Yukinori

\section{CITATION:}

Koyama, Yukinori. Effects of oral intake of hydrogen water on liver fibrogenesis in mice. 京 都大学, 2014, 博士 (医学)

ISSUE DATE:

2014-01-23

URL:

https://doi.org/10.14989/doctor.k17974

RIGHT: 


\begin{tabular}{|l|l|c|c|}
\hline 京都大学 & 博士（医学 ） & 氏 名 & 小 山 幸 法 \\
\hline 論文題目 & $\begin{array}{l}\text { Effects of oral intake of hydrogen water on liver fibrogenesis in mice } \\
\text { (マウスにおける水素水飲用による肝線維化抑制効果の検討) }\end{array}$ \\
\hline (詥)
\end{tabular}

\section{(論文内容の要旨 $)$}

【背景と目的】肝線維化は様々な肝傷害機転の共通の帰結であり、本邦のみならず世界に おいて主たる死因の一つである。近年肝線維化の原因として活性酸素の関与が注目されて いる。我々は選択的抗酸化活性剤として報告されている水素水を用いて肝線維化抑制効果 を検討した。さらに、そのメカニズムについて検討した。

【方法】マウス肝線維化の誘導モデルとして(1)四塩化炭素 $\left(\mathrm{CCl}_{4}\right)$ の腹腔内投与(2)チオアセ トアミド(TAA)の腹腔内投与(3)胆管結紮、の 3 種のモデルを用いた。それぞれの線維化誘 導の際に、自由飲水で水素水（水素水群）とコントロール水（コントロール水群）を与え た。メカニズムの検討のため、C57BL/6 マウスの正常肝より、コラゲナーゼ処理を行い遠 心により肝細胞の分離を行った。星細胞の分離には 2 段階のコラゲナーゼ、プロテアーゼ 処理の後、密度勾配遠心法を用いた。

【結果】

(1) $\mathrm{CCl}_{4} 、 \mathrm{TAA}$ モデルともにハイドロキシプロリン定量法、シリウスレッド染色等におい て、水素水群はコントロール水群に比して有意に肝線維化の形成が抑制されていた。

(2) これまで脳の虚血再灌流モデル等において、水素のヒドロキシラジカル $(\mathrm{OH} ・)$ 選択

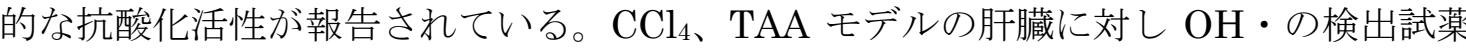
として知られる Hydroxyphenyl Fluorescein 染色を行い、水素水の飲用によりその産 生が抑制されていることが確認された。

(3) 胆管結紮モデルにおいて水素水の飲用は肝線維化抑制効果を示さなかった。また同モデ ルにおいては、コントロール水群においても肝臟内の $\mathrm{OH}$ ・産生は認められなかった。

(4) 肝細胞を分離培養し、アンチマイシンA（AMA）添加により酸化ストレスを誘導した。 AMA 投与により $\mathrm{OH}$ ・の増加を認め、それらは水素添加培地にて培養することにより 抑制された。AMA を添加した肝細胞では死細胞割合が増加したが、培地一の水素添加 により死細胞が減少した。

(5) 星細胞を分離し、プラスチックディッシュ上で培養を行った。水素添加培地においても 星細胞の活性化の指標に変化を認めなかった。星細胞に対しAMA による酸化ストレス 誘導を行ったが、水素水添加培地においても星細胞の活性化の状況に変化は見られなか った。AMA による酸化ストレス誘導下においても $\mathrm{OH} ・$ 陽性細胞は認めなかった。

【考察】これまで種々の抗酸化活性物質と肝線維化抑制効果についての報告は散見される が、活性酸素の中でも $\mathrm{OH} ・ の$ 役割に言及した論文は見られない。我々の細胞分離培養実 験の結果、水素の添加により肝細胞において $\mathrm{OH}$ ・の産生抑制と肝細胞死の軽減を観察し た。これらは、肝細胞における $\mathrm{OH} ・$ のコントロールが肝細胞死と密接に関連寸る可能性 を示唆する。肝細胞死はヒトにおいても $\mathrm{C}$ 型肝炎、 B 型肝炎、アルコールによる肝傷害の 主たる機転であり、肝細胞死を軽減することはそれに引き続く免疫反応、線維芽細胞の活 性化、肝線維化形成の抑制につながる。本研究の結果から、水素水は肝細胞傷害を抑制す ることで肝線維化形成を抑制したと考えられる。

一方胆管細胞傷害モデルである胆管結紮モデルではそれらの効果が見られなかった。同モ

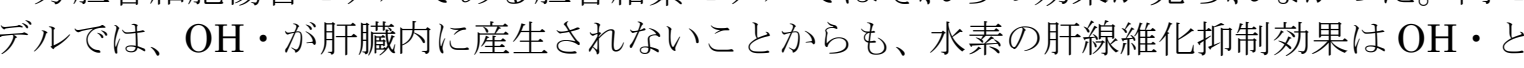
関連していることの証左が伺える。

これまで、活性酸素が星細胞の活性化に直接影響寸るという報告も見られるが、水素にお いては星細胞への直接の効果は見られなかった。

本研究により水素はヒドロキシルラジカルによる肝細胞傷害を軽減することにより、肝臓 線維化を軽滅することが示された。
（論文審査の結果の要旨）

肝線維化は様々な肝傷害機転の共通の帰結であり、主たる死因の一つである。肝線維化 の原因として活性酸素の関与が数多く報告されている。本学位申請者は近年抗酸化活性 剂として注目されている水素水を用いて肝線維化抑制効果を検討した。

マウス肝線維化モデルとして、(1)四塩化炭素 $\left(\mathrm{CCl}_{4}\right)$ の腹腔内投与(2)于オアセトアミト (TAA)の腹腔内投与(3)胆管結紮モデルを用いた。それぞれの線維化誘導の際に、自由飲 水で水素水とコントロール水を与えた。結果、CCl4、TAA モデルにおいては水素水群 において有意に線維化の程度の軽減効果が示された。またこれらのモデルでは肝臓内に ヒドロキシルラジカル $(\mathrm{OH} ・)$ が検出され、水素水群ではそれらの減少を認めた。胆 管結紮モデルでは肝臓内に $\mathrm{OH}$ ・は検出されず、水素水による線維化抑制効果も認めら れなかった。

メカニズムの検討のため、マウス肝細胞を分離しアンチマイシン A (AMA）添加によ り酸化ストレスを誘導した。AMA 投与により $\mathrm{OH} ・$ の増加を認め、それらは水素添加 培地での培養により抑制された。AMA を添加した肝細胞では死細胞割合が増加したが、 培地一の水素添加により死細胞が減少した。星細胞への水素の影響も検証を行ったが、 水素は星細胞のディッシュ培養での活性化、酸化ストレス誘導下の活性化にも影響を与 えなかった。

本研究は水素水の肝線維化抑制効果を示したの夕ならず、各肝傷害モデルにおける活性 酸素の関与の解明に貢献し、肝線維化克服の臨床に寄与寸るところが大きい。 したがって、本論文は博士（医学）の学位論文として価值あるものと認める。 なお、本学位授与申請者は、平成 25 年 12 月 2 日実施の論部内容とそれに関連した試 問を受け、合格と認められたものである。 